\title{
Aegean Enigma: The Rise and Fall of Vineyards DURing ANTIQUITY
}

\author{
Paulina Komar \\ iD http:/orcid.org/0000-0001-6580-223X \\ Cardinal Stefan Wyszyński University in Warsaw
}

\begin{abstract}
This paper argues that the rise and fall of north and central Aegean wine exportations was caused by economic factors, such as changes in wine supply. It demonstrates that these wines disappeared from southern Gaul and central Tyrrhenian Italy when these areas started to locally produce their own wine. At the same time, north and central Aegean wines were also ousted from the Black Sea region by both local products and cheaper imports from the southern Aegean. This shows that supply and demand governed commercial activities during the Classical and Hellenistic periods, which provides new evidence regarding the nature of the ancient Greek economy.
\end{abstract}

Keywords: wine, trade, Aegean, economy, antiquity.

In a paper of mine published in $2014^{1}$ particular emphasis was placed on the subject of wines from Thasos, Lesbos and Chios. These wines appeared frequently in both Greek and Latin written sources, especially during the Classical and Hellenistic periods, while the amphoras in which they were transported have been attested in various areas of the Mediterranean from the Archaic, Classical and Hellenistic age. Although Thasian and Lesbian containers disappeared from the archaeological record around the turn of the 3rd/2nd century BC and Chian vessels stopped appearing around the mid-1st century $\mathrm{AD}$, these wines continued to appear in medical texts (e.g. the Galenic Corpus) in contexts that suggested they were still being produced in the 2 nd century AD. The resulting conclusion was that when combined the evidence suggests that these islands continued to produce wines during the Roman age, but on a considerably smaller scale. However, exportations from these islands were no longer sought after in the Mediterranean, which might have been due to various reasons: 
1. A change in Roman taste (from Greek to Italian wines). ${ }^{2}$

2. A change in the ethnic origin of traders - during the Roman age Italian freedmen were the most predominant group involved in wine commerce, ${ }^{3}$ which might have influenced the preferred production places and favored trade routes.

3. South-Aegean competition - from the 3rd century BC Rhodian, Coan and Cnidian wines started to be produced on a larger scale, while during the 1st and 2nd century AD Cretan passum flooded the Italian markets. ${ }^{4}$ North-Aegean products could not compete against the cheaper, albeit less appreciated wines from southAegean vineyards. ${ }^{5}$

It should be emphasized that the hypothesis based on competition implies that during the Classical and Hellenistic periods the Mediterranean economy already included elements typical of a modern market economy, since competition based on price would probably not function in a situation where economic factors were ignored. In this paper, I argue that when there was demand for imports in the western Mediterranean and the Black Sea region, exportations from north and central Aegean vineyards blossomed. However, when local production became intensive enough to satisfy the demand, the need for importations ceased. Similarly, when cheaper alternative imports appeared, the more expensive imports were driven out of the market. This shows that economic factors such as supply and demand governed commercial exchange, and that it was price that mattered most for the consumers. Consequently, this implies that profit played an important part in ancient commercial exchange from its outset. Overall, this suggests that the nature of the ancient economy did not differ much from a modern market economy.

\section{Market or What?-Theoretical Assumptions}

What does a market economy really entail? First of all, it should be free from any ideological or social constraints, for example the social position of those engaged in commercial exchange should not interfere with economic forces. ${ }^{6}$ Secondly, it should have a broad geographical range, which crosses political boundaries. According to Wallerstein's world-system theory, capitalism was the first 'world-economy', which differed from earlier existing political entities that were classified as 'world-empires'. ${ }^{7}$ However, it cannot be excluded that pre-modern 'world-economies' existed during antiquity, some even argue that the Roman economic domination began before the formal political conquest of the Mediterranean. ${ }^{8}$ Currently, the discussion regarding the Roman economy remains polarized. The existence of a market economy during the Roman period has

\footnotetext{
The aristocratic character of these wines was demonstrated in Komar 2014b.

Komar 2020, Chapter 5.

Komar 2020, Chapter 3.

For the quality and possible consumers of south-Aegean wines, see Komar 2020, Chapter 2 and 4.

Martinat 2008.

Wallerstein 1974.

8 Carandini 1986; Woolf 1990, 52-53.
} 
been postulated by P. Temin, ${ }^{9}$ but due to the fragility of the evidence ${ }^{10}$ his model remains uncertain. Nevertheless, a number of scholars argue that "the historian of the Roman economy should have the courage to consider his subject in terms of a market economy even when the market lacks its unifying function at the world level." ${ }^{11}$ On the other hand, the so-called bazaar economy model created by P. Bang, ${ }^{12}$ which emphasizes the greater role of political factors with regards to how the ancient economy was governed, continues to be valid, despite the criticism it had received. ${ }^{13}$

Recent studies regarding the nature of the Greek economy during pre-Roman times also move the discussion further away from Finley and the primitivist view, and suggest the existence of 'Greek world-economies'. It has been commonly accepted that Greek cities created a homogeneous economic entity which was based on the free exchange of goods. According to Bresson, "L'économie de la Grèce des cités relève donc pleinement de la catégorie des économies à marché." ${ }^{14}$ Migeotte points out that during the Archaic age a step towards a market economy had already been taken by the Greeks when coins became gradually more important equivalent of goods used in commercial exchange, yet systematic 'mise en marché' should be attributed to the 5th century BC. Xenophon, writing in the 4th century BC, noted that there was a link between the supply of grain and wine and their prices, which dropped when agricultural products became more abundant, thus making cultivation of these goods less profitable - a perfect example of the rule of supply and demand operating in the late Classical age. ${ }^{15}$ Given the considerable economic development that may be observed in the Hellenistic period, ${ }^{16}$ the Greek economy can easily be called 'économie à marchés' (an economy 'with markets'), ${ }^{17}$ which means that markets did indeed play an important role, as they do in a modern market economy. This study aims in adding a further argument confirming the 'modernist' nature of the Greek economy demonstrating that trade, or to be more precise patterns of wine exchange were governed by the supply and demand rule.

\section{Economy or Politics: What Caused the Change in Wine Trade Patterns?}

Most of the Aegean centers that produced wine for export, such as Ilion, Corinth, Miletus, Samos, Ainos, Oisyme and Samothrace were restricted to satisfying demands within their own immediate regions. Akanthos and Mende in Chalkidiki, and the island of Peparethos, exported their products on a slightly larger scale, ${ }^{18}$ but it was only goods from

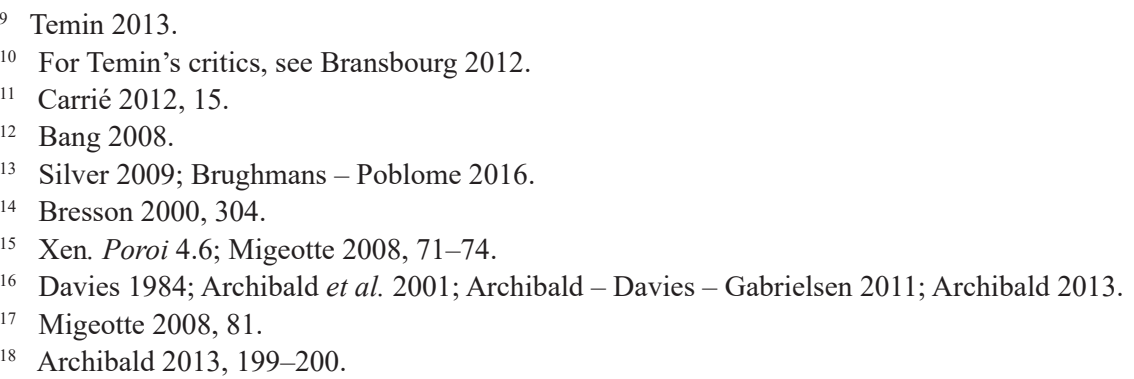


Thasos, Lesbos, Chios, Rhodes, Cos, Cnidus and Crete that were truly widely distributed. North and central Aegean (and by north Aegean I mean Thasos and Lesbos) wines were already being exported on a large scale during the Archaic age, while south-eastern Aegean products entered the stage in the late Classical or Hellenistic age, with Crete flourishing during the period of Roman domination. ${ }^{19}$ Although there is no final consensus regarding the content of these jars, it is almost certain that most Aegean amphoras, including Chian, Lesbian, Thasian, Peparethian, Mendean, Rhodian, Coan, Cnidian, Cretan, as well as Corinthian B vessels from Corcyra, carried wine. ${ }^{20}$

Amphoras from Thasos did not initially travel very far, but this changed during the late 6th century $\mathrm{BC}$ when jars from the Island reached Italy. ${ }^{21}$ Two centuries later, between 70 and 90 per cent of Thasian containers were exported beyond the island's immediate vicinity; most of them was destined for western and northern Black Sea coastal regions, whilst some also found their way to the Thracian and Macedonian interior. Between the 4th and 2nd century BC, Thasian was one of the most broadly distributed wines in the Eastern Mediterranean. ${ }^{22}$ Lesbian amphoras are very characteristic, being grey or red-colored containers, with massive cylindrical handles and a so-called 'rattail' that is formed by tapering down the lower handle attachments. ${ }^{23}$ Their production started in the 7th or even 8th century BC. ${ }^{24}$ According to literary testimonies they were exported to Egypt as early as during the 7 th century $\mathrm{BC} .{ }^{25} \mathrm{At}$ the same time, archaeological discoveries confirm that they were exported to the western Mediterranean and the Black $\mathrm{Sea}^{26}$ up until century 325/300 BC, when they disappear from the archaeological record. ${ }^{27}$ The island of Chios produced amphoras and exported wine from at least the 7th century $\mathrm{BC}$ until the 1st century $\mathrm{AD}$, but evidence regarding Chian exportation disappears after this date. ${ }^{28}$ So, what factors were behind the rise and fall of Thasian, Lesbian and Chian vineyards? It seems that wine exportations from these regions blossomed during the colonization period as well as in the early Classical age, when wine was not a common commodity in the Mediterranean and beyond. However, the development of viticulture and wine making in different centers of the Mediterranean and Black Sea regions was responsible for the demise of north and central Aegean exportations. Three case studies illustrate this pattern.

19 Komar 2020.

20 Komar 2020, Chapter 1.

Sacchetti 2013, 58.

Archibald 2013, 14, 200.

Dupont 1998, 156-159.

Clinkenbeard 1982, 248-249; Clinkenbeard 1986, 353; Whitbread 1995, 154.

Strabo 17.1.33.

6 Dupont 1998, 160-162.

7 Clinkenbeard 1986, 353.

28 Fiori - Joncheray 1975, 61; Whitbread 1995, 135; Bezeczky 2013, 50; Sacchetti 2013, 67. 


\section{a. The disappearance of Aegean and Etruscan wines from Gaul}

Aegean wines started to appear in southern Gaul at the end of the 7th century BC, and for more than a hundred years they were imported together with Etruscan and Phoenician products. Massalia was among the main consumption centers of imported wines during the 6th century $\mathrm{BC},{ }^{29}$ but when this Phocean colony started its own viticultural activity, the percentages of imported amphoras (Etruscan, Aegean and Phoenician) attested in the south of Gaul decreased. ${ }^{30}$ Wines from the Aegean, which were present in Massalia during the first half of the 6th century BC began to gradually disappear after 540/530 BC, being replaced with Massalian varieties. ${ }^{31}$ It seems that during the 5 th century $\mathrm{BC}$, trade between Massalia and both Etruria and the Eastern Mediterranean was replaced with trade between the colony and its neighboring settlements. ${ }^{32}$ A similar pattern may be observed in Spain: during the 7th and 6th century BC imported amphoras (mostly from Etruria) were very frequent, but their numbers started to decrease gradually during the late 6 th century $\mathrm{BC}$ and continued to diminish throughout the 5 th century $\mathrm{BC}$, which correlates with the increase in Massalian containers. ${ }^{33}$ Does this mean that Massalian products ousted Etruscan and Aegean wines? Bats associated this change in wine supply with the reorganization of trade in the Tyrrhenian area after the battle of Alalia in $535 \mathrm{BC} .{ }^{34}$ On the other hand, Dietler argues that Etruscan amphoras started to disappear from Gaul before the indigenous production of wine flourished, and suggests that the end of Etruscan exportation should rather be associated with political instability in Etruria during the 6th century BC, or with the actions of pirates from Liguria, who forced trade routes to be realigned. ${ }^{35}$ However, these events had little impact on trade with the Aegean, which also faded. Therefore, it seems likely that local production did indeed lead to there being more wine on the market, which resulted in imports from the Aegean and Etruria being unnecessary. This resembles the pattern of wine trade observed in Italy.

\section{b. Aegean and Etruscan wines in Italy}

North-Aegean wines appeared in Italy, Etruria in particular, during the Archaic age. Amphoras dated between the 7th and the 5th century BC from Attica, Clazomenae, Lesbos, Chios, Mende, Thasos, Samos and Miletus are widely attested in Etruscan cemeteries. ${ }^{36}$ Less abundant are Solokha I amphoras that were probably produced in Peparethos. ${ }^{37}$ Amphora evidence from the Archaic and early Classical period (600-400 BC) from

29 Bats 2012, 378, 385.

30 Py 1985, 84-85.

31 Bats 1998, 619-620.

32 Dietler 2010, 7.

33 Santmartí Grego et al. 1991, 86-87; Bats 1998, 622-623.

34 Bats 1998, 626-628.

35 Dietler 2010, 197.

36 Di Sandro 1981, 11-12; Albore Livadie 1985, 138-145; Slaska 1985, 19-21; Marangou-Lerat 2000, 72; Sacchetti 2013, 64-65, 75-76, 80-81, 93-95.

37 Doulgèri-Intzessiloglou - Garlan 1990, 388; Sacchetti 2013, 101-102. 
Latium is less abundant than from Etruria, but a few Corinthian A, Corinthian B, Samian, Mendean and Chian fragments were discovered in Roman necropoleis, ${ }^{38}$ in Villa dell'Auditorium in the Roman suburbs, ${ }^{39}$ on the Palatine Hill, ${ }^{40}$ and in the Temple of Castor and Pollux in the Forum Romanum. ${ }^{41}$ It seems that northern and central Aegean wine imports stopped sometime during the 5th century $\mathrm{BC}$, while during the late 3rd century $\mathrm{BC}$ south Aegean wines entered the stage. ${ }^{42}$ Nevertheless, the scarcity of evidence for the 4th and most of the 3rd century BC may also be due to other reasons, such as the abandonment of the practice of depositing pottery as funerary offerings (which provide most of the archaic amphora deposits) and the fact that residential contexts provide more fragmentary material, which is more difficult to identify. ${ }^{43}$

On the other hand, as long as the Etruscans were sending their wines to Gaul and Spain, Aegean importations were welcomed in Italy. However, during the 5th century $\mathrm{BC}$ Gaul and Spain turned towards Massalia, which led to more Etruscan wine being available on the Apennine Peninsula. Furthermore, during the late 5th century BC viticultural activity in Magna Graecia began. Production of the so called 'Graeco-Italic' amphoras occurred in places that include Sicily, Bruttium, Lucania and Campania. ${ }^{44}$ Moreover, literature, archaeobotanical evidence and the appearance of wine presses attested in archaeological record indicate a gradual growth in vine cultivation and grape processing in the southern part of the Apennine Peninsula. This evidence should leave no doubt that Sicily and southern Italy enjoyed a developed, large scale wine industry. The wine was not only consumed locally, but was also transported to different parts of Italy, as suggested by MGS amphora findings. Graeco-Italic amphoras produced in southern Italy were also exported overseas to north Africa, Catalonia, the Balearic Islands, south Gaul, the Aegean region and the Eastern Mediterranean, ${ }^{45}$ which means that Italian wine production must have exceeded local needs. Therefore, it seems likely that when Magna Graecia started to produce wine on a large scale which coincided with there being more Etruscan wine on the market, foreign imports were no longer necessary, ${ }^{46}$ which again shows that supply and demand influenced commercial exchange patterns.

\section{c. The disappearance of north-Aegean wines from the Black Sea region}

During the Archaic age the northern Black Sea area imported products in amphoras from Chios, Lesbos, Thasos, Clazomenae, Samos, Miletus, Corinth, ${ }^{47}$ and these imports con-

38 Gras 1983, 1068; Sacchetti 2013, 30.

39 Di Giuseppe 2006, 207, tab. 20.

40 Zevi 1985, 119; Sacchetti 2013, 76.

41 Slej 2008, 204-208. These were dated between 550 and 300 BC.

42 Komar 2020, Chapter 1.5.

43 Sacchetti 2013, 11.

44 Vandermersch 1994, 59-92.

45 Vandermersch 1994, 123-147.

46 They appeared again at the end of the $3 \mathrm{rd} /$ beginning of the 2 nd century BC (see Komar 2020), but this issue is beyond the scope of this paper.

47 Monakhov - Kuznetzova 2017, 66. 
tinued until the end of the Classical period. Chian, Lesbian and Thasian wines were common in this area until the early 4th century BC. Thasian and to a lesser degree Chian were also among the most common imports in the east Balkan interior. ${ }^{48}$ During the 4 th century BC wine production in Sinope, Heraclea and Chersonesus started, which resulted in wines from these areas appearing on the Black Sea market as competition for north and central Aegean varieties. ${ }^{49}$ At the same time, Rhodian, Coan, Cnidian and Erythraian importations, which started during the first half of the 4th century $\mathrm{BC}$, became more and more common. By the end of the 3rd century BC Thasian and Chian imports to the Northern Black Sea region stopped. ${ }^{50}$ The increase in discoveries of Rhodian stamps in this area correlates perfectly with a decrease in the amount of Thasian stamps. ${ }^{51}$ Similarly, in the Balkan region there are no Thasian amphoras later than the second quarter of the 3rd century BC, which is when Rhodian vessels began to appear in the archaeological material. ${ }^{52}$ Therefore, the hypothesis regarding south-Aegean competition seems probable, especially if we consider that wines such as Rhodian and Coan were considerably cheaper than north and central Aegean products.

It is true that there is no comparable evidence regarding the prices of these wines, but Salviat mentions a 3rd century BC inscription which revealed that an amphora (around 22 1) of Chian wine cost 18 drachmas, whereas the same amount of Thasian wine was sold for 20 drachmas, which was a fifth of the price of a good slave. ${ }^{53}$ At the same time, Martial referred to Cretan wine as 'mulsum pauperis' ${ }^{54}$ while Fronto mentioned that it was among the most popular and cheapest drinks (like those from Sagunto and Tarraconensis) during the 2nd century AD. ${ }^{55}$ Furthermore, we know from Pliny that Coan and Rhodian wines were similar, ${ }^{56}$ and that the former was sold at half or three quarters of the price of wine from Cnidus at the beginning of the 2 nd century BC on Delos. ${ }^{57}$ Moreover, Coan wine was always purchased in larger quantities than Cnidian, ${ }^{58}$ which also suggests its lower quality. In addition, during the 1 st century BC trade involving Dressel 2-4 amphoras was associated with the Roman army. ${ }^{59}$ Dressel 2-4 were imitations of Coan containers, and it is likely that they were used to transport wine that was similar to Coan. Considering that soldiers are usually not provided with the highest-quality products, this would be further evidence that wine from Cos, similar to other south-Aegean wines, was relatively cheap.

Archibald suggests that the drop in Thasian exports might have been caused by a disruption in commercial patterns during the reign of Lysimachus, but admits that a change

48 Archibald 2013, 201.

49 Monakhov - Kuznetzova 2017, 64.

50 Monakhov - Kuznetzova 2017, 74-78.

51 Conovici 2005, 108-111, fig. 7-9. It seems that the relative frequency of Thasian amphora eponyms in Istros, Tomis and Kallatis declined around 250-230 BC, whereas Rhodian examples increased in this period.

52 Archibald 2013, 202.

53 Salviat 1986, 180; Salviat - Tchernia 2013, 219.

54 Mart. 13.106

55 Fronto De eloq. 1.4; Tchernia 2011, 257-258, 345-346.

56 Pliny HN 14.79: Rhodium Coo simile est.

57 Tchernia 1986, 105; after Larsen 1938, 392-394.

58 Larsen 1938, 393.

59 Purcell 1985, 14. 
in demand (caused by demographic and social changes) should also be considered. ${ }^{60}$ She also notes that "Thasian wine jars disappeared from the Balkan region after the second quarter of the 3rd century BC, conceding to Rhodian, Koan, Mesambrian, and Pontic producers." ${ }^{\prime 61}$ According to Tzochev, the change in trade routes that favored southAegean beverages, the decline of Athens as a commercial hub, and the destruction of rural territories in the Bosporan Kingdom and Dobruja - the main sources of cereals in the region during the mid-3rd century $\mathrm{BC}$, might have impacted upon wine trading patterns, but the evidence for this is vague. However, if we accept that ancient trading relations operated in a profit-oriented reality, it seems that the sale of Thasian wine on Black Sea markets must have influenced the growth of wine production on the island. This increased Thasian wine supply in the Black Sea region must have caused its price to fall. Thus, selling their wine on distant markets became less profitable for Thasos' wine producers, which forced them to look to other markets on, and close to their island. ${ }^{62}$ Similar mechanisms might explain the reduction of Lesbian and Chian exportations. These luxury wines were expensive and exporting them was lucrative as long as they maintained a high price. When the amount of wine on the Black Sea market grew due to local products and cheap south-Aegean imports, the prices of north and central Aegean vintages must have dropped, which made exporting them unprofitable.

\section{Conclusions}

Considering the case studies presented above one should realize that the rise and fall of north and central Aegean wine exportations was caused by economic factors, such as the changes in wine supply. First of all, Aegean wines disappeared from southern Gaul and central Tyrrhenian Italy when local wine production was developed. Secondly, they were pushed out from the Black Sea region by both local products and cheaper imports from the southern Aegean. Consequently, Thasos and Lesbos seemingly stopped exporting wines, as the containers in which they were transported completely disappeared from the archaeological record. ${ }^{63}$ According to Kourakou-Dragona, Lesbos and Thasos started to produce olive oil ${ }^{64}$ but there is no evidence that it was exported. Chios adapted to the new conditions to a certain degree, as the island continued to produce wine amphoras until the beginning of the Roman imperial period. The exporting of wine from the island was probably already gradually being negatively impacted by exportations from Rhodes and Cos, but the birth of Cretan vineyards, which appeared during the 1st and blossomed during the 2 nd century $\mathrm{AD}$, was the final nail in the coffin. However, it seems that the island soon recovered and changed its commercial specialization, given that amphoras

\footnotetext{
60 Archibald 2013, 201.

61 Archibald 2013, 202.

62 Tzochev 2016.

63 See Salviat 2013, 99 regarding the disapearance of Thasian wine.

64 Kourakou-Dragona 2013, 221.
} 
from the Late Hellenistic and Imperial period that are attributed to Chios most probably carried olive oil. ${ }^{65}$

All the above shows that supply and demand governed commercial activities during the Classical and Hellenistic periods. If there was no alternative, expensive and famous vintages were imported, but when local viticulture was developed enough to satisfy the demand it cornered the market. In a similar way, cheaper imports were able to knock the more expensive products out of the game. Therefore, it seems that the price, competition, and the market were the driving forces behind wine commerce during the Classical and Hellenistic periods, which means that this study further bolsters 'economy with markets' theory. In addition, considering the global range of these phenomena one may suggest that this is one step closer to a 'market economy' model. In any case, this study provides an argument for supporters of the modernist vision of the Greek economy.

\section{BIBLIOGRAPHY}

Albore Livadie, C. (1985), La situazione in Campania, in: AA.VV., Il commercio etrusco arcaico, Roma: $127-154$.

Archibald, Z. H. (2013), Ancient Economies of the Northern Aegean: Fifth to First Centuries BC, Oxford.

Archibald, Z. H., Davies, J., Gabrielsen, V. (2011), The Economies of Hellenistic Societies, Third to First Centuries BC, Oxford-New York.

Archibald, Z. H., Davies, J., Gabrielsen, V., Oliver, G. (2001), Hellenistic Economies, London-New York.

Bang, P. F. (2008), The Roman Bazaar: A Comparative Study of Trade and Markets in a Tributary Empire, Cambridge.

Bats, M. (1998), Marseille archaïque. Étrusques et Phocéens en Méditerranée nord-occidentale, MEFRA 110: 609-633.

Bats, M. (2012), L'arrivée du vin étrusque sur le litoral del Méditerranée nord-occidentale $\left(\mathrm{VI}^{\mathrm{e}}-\mathrm{V}^{\mathrm{e}} \mathrm{s}\right.$. av. J.-C.), in: A. Ciacci, P. Rendini, A. Zifferero (eds.), Archeologia della vite e del vino in Toscana e nel Lazio. Dalle tecniche dell'indagine archeologica alle prospettive della biologia molecolare, Firenze: 377-389.

Bezeczky, T. (2013), The Amphorae of Roman Ephesus, Vienna.

Bransbourg, G. (2012), Rome and the Economic Integration of Empire, ISAW Working Papers 3, http:// dlib.nyu.edu/awdl/isaw/isaw-papers/3 (accessed: 10 May 2020).

Bresson, A. (2000), La cité marchande, Bordeaux.

Brughmans, T., Poblome, J. (2016), Roman Bazaar or Market Economy? Explaining Tableware Distributions through Computational Modelling, Antiquity 90: 393-408.

Carandini, A. (1986), Il mondo della tarda antichità visto attraverso le merci, in: A. Giardina (ed.), Società romana e impero tardoantico, vol. 3: Le merci. Gli insiediamenti, Roma: 3-19.

${ }^{65}$ See amphoras Dressel 24 similis, for example Opait - Tsaravopoulos 2011, 317; Panella - Rizzo 2014, 322. 
Carrié, J.-M. (2012) Were Late Roman and Byzantine Economies Market Economies? A Comparative Look at Historiography, in: C. Morrisson (ed.), Trade and Markets in Byzantium, Washington: $13-26$.

Clinkenbeard, B. D. (1982), Lesbian Wine and Storage Amphoras: A Progress Report on Identification, Hesperia 51: 248-268.

Clinkenbeard, B. D. (1986), Lesbian and Thasian Wine Amphoras, in: J. Y. Empereur, Y. Garlan (eds.), Recherches sur les amphores grecques, Athens: 353-362.

Conovici, N. (2005), The Dynamics of Trade in Transport Amphoras from Sinope, Thasos and Rhodos on the Western Black Sea Coast: A Comparative Approach, in: V. Stolba, L. Hannestad (eds.), Chronologies of the Black Sea Area in the Period c. 400-100 BC, Aarhus: 97-117.

Davies, J. K. (1984), Cultural, Social and Economic Features of the Hellenistic World, $C A H^{2}$, vol. VII, part 1, Cambridge: $257-320$.

Di Giuseppe, H. (2006), I reperti, in: A. Carandini, M. T. D’Alessio, H. Di Giuseppe (eds.), La fattoria e la villa dell'Auditorium nel quartiere Flaminio di Roma, Roma: 201-211.

Di Sandro, N. (1981), Appunti sulla distribuzione delle anfore commerciali greche in Campania tra l'VIII sec. e il 273 a.C., AION(archeol) 3: 1-14.

Dietler, M. (2010), Archaeologies of Colonialism: Consumption, Entanglement, and Violence in Ancient Mediterranean France, Berkeley.

Doulgéri-Intzessiloglou, A., Garlan, Y. (1990), Vin et amphores de Péparéthos et d'Ikos, BCH 114: 361-389.

Dupont, P. (1998), Archaic Greek Transport Amphoras, in: R. M. Cook, P. Dupont (eds.), East Greek Pottery, London-New York: 142-191.

Fiori, P., Joncheray, J.-P. (1975), L'Épave de la Tradelière. Premiers résultats des fouilles entreprises en 1973, Cahiers d'archéologie subaquatique 4: 59-70.

Gras, M. (1983), Vin et société à Rome et dans le Latium à l'époque archaïque, in: AA.VV., Modes de contacts et processus de transformation dans les societies anciennes, Roma: 1067-1075.

Komar, P. (2014a), Consumption of Greek Wines in Roman Italy — between Literary and Archaeological Evidence, Food and History Journal 12/3: 99-131.

Komar, P. (2014b), Greek Wines for the Roman Elite: In Search of Eastern Luxuries on Western Tables, Eos 101: 227-244.

Komar, P. (2016), Wines from Cyprus and Cilicia in Antiquity: Taste and Trade, Electrum 23: 155-185.

Komar, P. (2020), Eastern Wines on Western Tables: Consumption, Trade and Economy in Ancient Italy, Leiden.

Kourakou-Dragona, S. (2013), La vigne et le vin dans le monde grec ancien, Athènes.

Larsen, J. A. O. (1938), Roman Greece, in: T. Frank (ed.), An Economic Survey on Ancient Rome, Baltimore: $259-498$.

Marangou-Lerat, A. (2000), Le plus agréable des vins grecs, in: C. Cremonesi, D. Tomasi (eds.), L'avventura del vino nel Bacino del Mediterraneo: itinerari storici ed archeologici prima e dopo Roma, Conegliano: 71-85.

Martinat, M. (2008), L'économie moderne entre justice et marché, in: Y. Roman, J. Dalaison (eds.), L'économie antique, une économie de marché?, Lyon-Paris: 253-262.

Migeotte, L. (2008), Les cités grecques: une économie à plusieurs niveaux, in: Y. Roman, J. Dalaison (éds.), L'économie antique, une économie de marché?, Lyon-Paris: 69-86.

Monakhov, S., Kuznetsova, E. (2017), Overseas Trade in the Black Sea Region and the Formation of the Pontic Market from the First Century BCE to the Third Century CE, in: V. Kozlovskaya (ed.), The Northern Black Sea in Antiquity: Networks, Connectivity, and Cultural Interactions, Cambridge: $59-99$.

Opait, A., Tsaravopoulos, A. (2011), Amphorae of Dressel 24 Similis Type in the Central Aegean Area (Chios-Erythrai-Kyme), The Annual of the British School at Athens 106: 275-323.

Panella, C., Rizzo, G. (2014), Ostia VI. Le terme del Nuotatore, (Studi miscellanei 38), Roma.

Purcell, N. (1985), Wine and Wealth in Ancient Italy, JRS 75: 1-19. 
Py, M. (1985), Les amphores etrusques de Gaule meridionale, in: AA.VV., Il commercio etrusco arcaico, Roma: 73-94.

Sacchetti, F. (2013), Les amphores grecques dans le nord de l'Italie: Echanges commerciaux entre les Apennins et les Alpes aux époques archaïque et classique, Paris-Aix-en-Provence.

Salviat, F. (1986), Le vin de Thasos. Amphores, vin et sources écrites, in: J.-Y. Empereur, Y. Garlan (eds.), Recherches sur les amphores grecques, Athens: 145-195.

Salviat, F. (2013), Vignes et vins anciens de Maronée à Mendé, in: F. Salviat, A. Tchernia (eds.), Vins, vignerons et buveurs de l'antiquité, Rome: 71-100.

Salviat, F., Tchernia, A. (2013), Les appellations d'origine dans l'antiquité grecque et romaine, in: F. Salviat, A. Tchernia (eds.), Vins, vignerons et buveurs de l'antiquité, Rome: 217-226.

Santmartí Griego, E. et al. (1991), La presencia commercial etrusca en la Emporion arcaica, determinada a partir de las ánforas, in: J. Remesal Rodríguez, O. Musso (eds.) La presencia de material etrusco en la Península Ibérica, Barcelona: 83-94.

Şenol, A. K. (2007), Hellenistik Dönem'de Khios ve Lesbos Şarabının Mısır'a İhracatı [The Exportation of Khian and Lesbian Wine to Egypt during the Hellenistic Period], Arkeoloji Dergisi 9: $103-128$.

Silver, M. (2009), Historical Otherness, the Roman Bazaar, and Primitivism: P.F. Bang on the Roman Economy, JRA 22: 421-443.

Slaska, M. (1985), Le anfore da trasporto a Gravisca, in: AA.VV., Il commercio etrusco arcaico, Roma: $19-21$.

Slej, K. (2008), Transport Amphorae, in: K. Slej, M. Cullhed (eds.), The Temple of Castor and Pollux II, 2. The Finds and the Trenches, Roma: 201-282.

Tchernia, A. (1986), Le vin de l'Italie romaine. Essai d'histoire économique d'après les amphores, Roma.

Temin, P. (2013), The Roman Market Economy, Princeton.

Tzochev, C. (2016), Markets, Amphora Trade and Wine Industry: The Case of Thasos, in: E. M. Harris, D. M. Lewis, M. Woolmer (eds.), The Ancient Greek Economy: Markets, Households and CityStates, Cambridge-New York: 230-253.

Vandermersch, C. (1994), Vins et amphores de Grande Grèce et de Sicile IVE-III ${ }^{e}$ s. avant J.-C., Naples.

Wallerstein, I. M. (1974), The Modern World-System, vol. 1: Capitalist Agriculture and the Origins of the European World-Economy in the Sixteenth Century, New York-London.

Whitbread, I. K. (1995), Greek Transport Amphorae: A Petrological and Archaeological Study, Athens. Woolf, G. (1990), World-systems Analysis and the Roman Empire, JRA 3: 44-58.

Zevi, F. (1985), La situazione nel Lazio, in: AA.VV., Il commercio etrusco arcaico, Roma: 119-125. 